\title{
Grass Mix Pollen Antigen IgA Antibody Measurement
}

National Cancer Institute

\section{Source}

National Cancer Institute. Grass Mix Pollen Antigen IgA Antibody Measurement. NCI

Thesaurus. Code C130105.

A measurement of the grass mix pollen antigen IgA antibody in a biological specimen. 